НАУКОВИЙ ВІСНИК

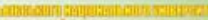

tanimail

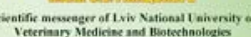

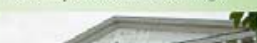

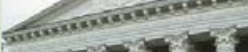

望

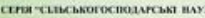
Tov 21 Nin 90

2019
Науковий вісник Дьвівського національного університету ветеринарної медицини та біотехнологій імені С.3. Гжицького. Серія: Сільськогосподарські науки

\author{
Scientific Messenger of Lviv National University \\ of Veterinary Medicine and Biotechnologies. \\ Series: Agricultural sciences
}

ISSN 2519-2698 print

https://nvlvet.com.ua/index.php/agriculture

doi: $10.32718 /$ nvlvet-a9009

UDC 631.524

\title{
Prospects of transgenic plants in the agro-sphere of Lviv region
}

\author{
R.P. Paranjak, B.M. Kalyn, B.V. Gutyj \\ Stepan Gzhytskyi National University of Veterinary Medicine and Biotechnologies Lviv, Ukraine
}

Article info

Received 06.02.2019

Received in revised form 11.03 .2019

Accepted 12.03.2019

Stepan Gzhytskyi National University of Veterinary Medicine and Biotechnologies Lviv, Pekarska Str., 50, Lviv, 79010, Ukraine.

Tel.: +38-096-289-52-40

E-mail: kalynb@bigmir.net
Paranjak, R.P., Kalyn, B.M., \& Gutyj, B.V. (2019). Prospects of transgenic plants in the agro-sphere of Lviv region. Scientific Messenger of Lviv National University of Veterinary Medicine and Biotechnologies. Series: Agricultural sciences, 21(90), 54-58. doi: 10.32718/nvlveta9009

The state and prospects of the use of transgenic plants in agriculture of Lviv region are considered in the paper. Transgenic plants are a kind of genetically modified organisms obtained by biotechnological methods using trans-transfer (between unrelated species) genes. In recent years, such cultures have become widespread in the world. The vast majority of soy, corn and other crops are planted with GM varieties. In the EU countries there is no broad perception of such cultures and there are significant restrictions on their distribution. Approximately 70 types of GMOs are allowed in the EU, including many decorative products (flowers) and about 58 GMOs for use in food and feed. In the world, 168 lines of genetically modified plants: corn, rape, cotton, potatoes, soya, rice, tomatoes, wheat and others were registered and allowed to be used for industrial production of food and feed. Our country also has some experience in obtaining transgenic organisms. According to unofficial data, in Ukraine transgenic 60$70 \%$ soybeans, 10-20\% corn, 5\% rape. In the near future, Ukraine should develop a clear concept of attitude towards GMOs, and the absence of a position on this issue complicates the planning of activities of the agro-sector. In the Lviv region there are prospects for growing GM varieties of soybean, corn and sunflower; there is evidence that a significant part of the crops of the first belongs to the modified varieties. Growing of GM sunflower in comparison with the usual one will have limited competitive advantages. Of the other crops that the area is specialized in, one can name potatoes whose GM varieties are used mainly for technical needs, and wheat, whose GM varieties have not yet been sufficiently tested. In the world market, there is a demand for genetically modified crops, an estimated $68 \%$ of Ukrainian agroholdings claim to be willing and able to grow GM crops for their legalization in Ukraine.

Key words: agrarian sector, transgenic plant organism, crop production, Lviv region.

\section{Перспективи трансгенних рослин у агросфері Львівщини}

\author{
Р.П. Параняк, Б.М. Калин, Б.В. Гутий \\ Львівський національний університет ветеринарної медицини та біотехнологій імені С.3. Гжиџького \\ м. Львів, Україна
}

У роботі розглянуто стан та перспективи використання трансгенних рослин у сільському господарстві Львівської області. Трансгенні рослини є різновидом генетично модифікованих організмів, одержаних біотехнологічними методами із використанням транс-переносу (між неспорідненими видами) генів. Протягом останніх років такі культури набули значного поширення у світі; переважна більшість площ сої, кукурудзи та значна інших культур засіяні ГМ сортами. У країнах ЄС відсутнє широке сприйняття таких культур та є суттєві обмеження на їх поширення. У СС дозволено близько 70 видів ГМО, у тому числі чимало декоративних продуктів (квіти), та близько 58 ГМО для використання у харчових продуктах та кормах. Загалом у світі зареєстровано $i$ допущено до промислового виробництва продуктів харчування та кормів 168 ліній генетично модифікованих рослин: кукурудзи, ріпаку, бавовни, картоплі, сої, рису, томатів, пшениці та інших. У намій краӥні також є певний досвід отримання трансгенних організмів. За неофіџійними даними, в Украӥні трансгенні 60-70\% сої, 10-20\% кукурудзи, 5\% - ріпаку. У найближчій перспективі Україні слід виробити однозначну конџепцію ставлення до ГМО, відсутність якої ускладнює планування напрямів діяльності агросектору. У Львівській області є перспективи вирощування ГМ сортів сої, кукурудзи та соняшнику. Вирощування ГМ соняшнику 
порівняно зі звичайним буде мати обмежені конкурентні переваги. 3 інших культур, на виробництві яких спеціалізується область, можна відмітити картоплю, ГМ сорти якої використовують переважно для технічних потреб, та пшеницю, ГМ сорти якої ще не були достатньо апробовані. На світовому ринку існує попит на генетично модифіковані культури, за оиінками близько б8\% украӥнських агрохолдингів заявляють про бажання та можливості вирощувати ГМ культури за їх легалізацї̈ в Украӥні.

Ключові слова: аграрний сектор, трансгенний рослинний організм, продукція рослинництва, Львівська область.

\section{Вступ}

Використання трансгенних організмів є одним із найбільш контраверсійних питань сьогодення. Практика їхнього використання у розвинених країнах має виражений господарсько-економічний ефект. Вирощування таких рослин дозволяє знизити обсяги застосування пестицидів і збільшити врожайність. Разом із тим 3 погляду значення для екологічних спільнот використання у широкій практиці, поширення нових організмів, які належать до трансгенних, $є$ питанням, котре не можна ігнорувати попри те, що більшість проблем наразі носять потенційний характер.

Трансгенний рослинний організм - це один з видів генетично модифікованих організмів (ГМО) рослинного походження. В Україні діє закон (Zakon Ukrainy), що регулює безпеку обігу ГМО та продукції. У першій статті цього закону дано визначення: генетично модифікований організм, живий змінений організм (ГМО) - будь-який організм, у якому генетичний матеріал був змінений за допомогою штучних прийомів переносу генів, які не відбуваються у природних умовах, а саме: рекомбінантними методами, які передбачають формування нових комбінацій генетичного матеріалу шляхом внесення молекул нуклеїнової кислоти (вироблених у будь-який спосіб зовні організму) в будь-який вірус, бактеріальний плазмід або іншу векторну систему та їх включення до організму-господаря, в якому вони зазвичай не зустрічаються, однак здатні на тривале розмноження; методами, які передбачають безпосереднє введення в організм спадкового матеріалу, підготовленого ззовні організму, включаючи мікроін'єкції, макроін'єкції та мікроінкапсуляції; злиття клітин (у тому числі злиття протоплазми) або методами гібридизації, коли живі клітини 3 новими комбінаціями генетичного матеріалу формуються шляхом злиття двох або більше клітин у спосіб, який не реалізується за природних обставин.

Поширення продуктів з ГМО у світі та в Україні зокрема перетворюється у реальність. Тому, в контексті розвитку вітчизняного аграрного сектору важливо розуміти межі, напрямки та перспективи застосування культур, геном яких модифіковано, для виробництва конкурентоспроможної продукції в умовах виходу на світові ринки.

У даній роботі розглянуто потенційний економічний ефект та ризики для довкілля у екосистемах різного типу у Львівської області за умови запровадження трансгенних рослинних організмів.

Аналіз останніх досліджень $і$ публікацій. Україна приєдналася до Картахенського протоколу про біобезпеку Конвенції про біорізноманіття (від 12/09/2002), що декларує сприяння забезпеченню належного рівня захисту від потенційних ризиків, пов'язаних із поширенням ГМО (Oblat, 2014), засвідчивши позицію щодо підтримки нею необхідності застосування скоордино- ваних заходів для забезпечення належного рівня захисту в галузі використання сучасних біотехнологій i, зокрема, ГМО.

Перші трансгенні рослини були одержані у 1983 р.; перший харчовий ГМ продукт (сир) - виготовлений із використанням генетично модифікованого ферменту - був дозволений у США в 1990 p. (Rudyshyn, 2011). Початок комерційним посівам трансгенних сортів поклали не так давно - у 1996 р., але вже сьогодні вони займають кожен десятий гектар у світі. Незважаючи на опозицію у певних колах, нові сорти трансгенних рослин швидко завойовують популярність у світі; зокрема, площа під чотирма найбільш поширеними культурами (соя, кукурудза, бавовник, ріпак) складає майже $30 \%$ світових посівів. Серед країн, де найбільші площі зайняті трансгенними культурами, називають передусім країни західної півкулі: США, Канада, Аргентина, Бразилія. Чимало таких культур у Китаї, нещодавно (з 2011 року) Індія значною мірою перейшла на використання генетичномодифікованої бавовни. У багатьох державах генноінженерні сорти переважають над традиційними. Так, у 2010 р. 93\% площ сої в США, 99\% в Аргентині, 75\% у Бразилії висіяли ГМ-насінням. Для кукурудзи це відповідно $86 \%, 86 \%$ та $56 \%, 88 \%$ ріпаку в США i 94\% у Канаді трансгенні (Levenko, 2011).

Набагато обережніше ставлення до ГМО у Європі. Важливим принципом європейського права є принцип перестороги (Malus, 2016). Країни Свропейського союзу неодноразово скасовували дозволи та піддавали забороні використання тих чи інших ГМО, зокрема трансгенних рослин. У США поширена думка, що 3 боку ЄС діє неоголошений мораторій на імпорт продуктів, у створенні яких було використано методи біотехнології - відкриті суперечки з цих питань розпочались фактично у 2003 році. Румунія, що вступила у ЄС 2007 року, зазнала збитків, оскільки була змушена відмовитись від вирощування ГМ сої, стійкої до дії деяких гербіцидів (Bashuk, 2017). 32003 року СС запровадив, ймовірно, найбільш жорсткі правила щодо регуляції обігу ГМО (Davison, 2010). Серед країн ЄС найбільше поширення у сільському господарстві набули ГМО у Франції, Італії, Іспанії та Великобританії (Khmara, 2017). Популярністю тут користуються так звані арктичні яблука, що не коричневіють на зрізі, стійкі до гниття помідори Flavr Savr, картопля Amflora, що продукує крохмаль певного типу, “блакитна" троянда Suntory тощо. Серед ГМО рослин, що були одними з перших, варто згадати тютюн - ще 1986 року у Франції набув поширення стійкий до хвороб та шкідників тютюн. У ЄС дозволено до використання також два види бавовни і три види кукурудзи, проте у 2015 році 19 держав-членів ЄС звернулися до Європейської комісії з проханням про заборону на їх території ГМ кукурудзи MON 810 (а також картоплі Amflora). Серед держав, що зверну- 
лись, - наш сусід Польща. Аргументом на користь заборони $\epsilon$ постанова уряду 2013 року та дані про те, що пилок генномодифікованої кукурудзи завдає шкоди медоносним рослинам і може викликати важкі наслідки для бджолярства.

Загалом у СС дозволено близько 70 видів ГМО, в тому числі чимало декоративних продуктів (квіти) та близько 58 ГМО для використання у харчових продуктах та кормах (Malus, 2016). Згідно ж з базою даних AGBIOS (Bashuk, 2017), у світі зареєстровано і допущено до промислового виробництва їжі та кормів 168 ліній генетично модифікованих рослин: кукурудзи, ріпаку, бавовни, картоплі, сої, рису, томатів, пшениці та ін.

Треба розрізняти ГМО та генетично модифікований продукт - продукт, вироблений за допомогою чи з використанням ГМО. У ході приготування продукту часто генетична інформація втрачається. Щобільше прихильники генетично модифікованої продукції стверджують, що у випадку продуктів харчування чужорідні вставки повністю руйнуються в системі травлення тварин і людини (Bashuk, 2017).

\section{Результати та їх обговорення}

У Львівській області активно розвивається рослинництво, причому останніми роками спостерігаємо стале зростання врожайності основних сільськогосподарських культур (Baza danykh Holovnoho upravlinnia statystyky u Lvivskii oblasti). Важливим показником спеціалізації $є$ структура площ, зайнятих основними культурами. До таких можна віднести зернові, кормові та картоплю. Інші культури займають менш як 15\% кожна і від 6 до 28\% (у різні роки) в сукупності. Станом на 2018 рік у структурі посівних площ сільськогосподарських культур 44\%, або 295,9 тис. га займали зернові (рис. 1), далі у порядку спадання площ картопля, кормові культури, ріпак і кольза (ріпак ярий), соя, соняшник, овочеві культури, буряк цукровий.
Цікавою є динаміка основних культур: у 1990 році кормові культури займали 44\% й посідали перше місце, оскільки однією з причин була потреба підтримки тваринництва. Зернові займали $35 \%$, картопля $9 \%$ і $8 \%$ - інші культури з перелічених на рис. 1.3 плином часу частка зернових зростала (максимум 50\% площ у 2008 році), а кормових - стрімко зменшувалась. Для картоплі є характерним плавне збільшення до $18 \%$ у 2007 та 2010 роках. 32010 року можна помітити стрімкий ріст інших культур. Динаміку проілюстровано на рис. 2.

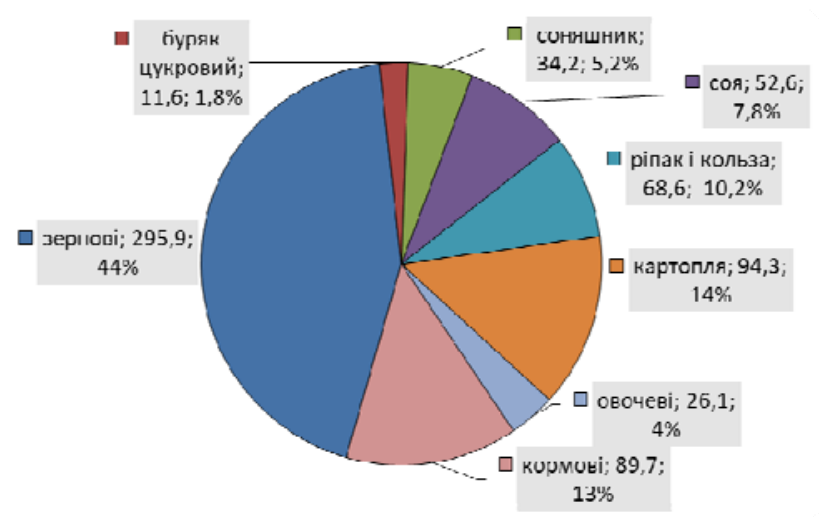

Рис. 1. Посівні площі основних сільськогосподарських культур у Львівській області в 2018 році (культура; площа, тис. га; відсоток від усіх культур) (Baza danykh Holovnoho upravlinnia statystyky u Lvivskii oblasti)

У 2012 році категорія “інші” випередила картоплю, а з 2013 року й кормові культури і продовжує стрімко зростати. Якщо лінійна тенденція останніх п’яти років збережеться, то до 2022 року ця категорія випередить зернові, а тому слід уважно вивчити культури, площі під якими зростають найшвидше.

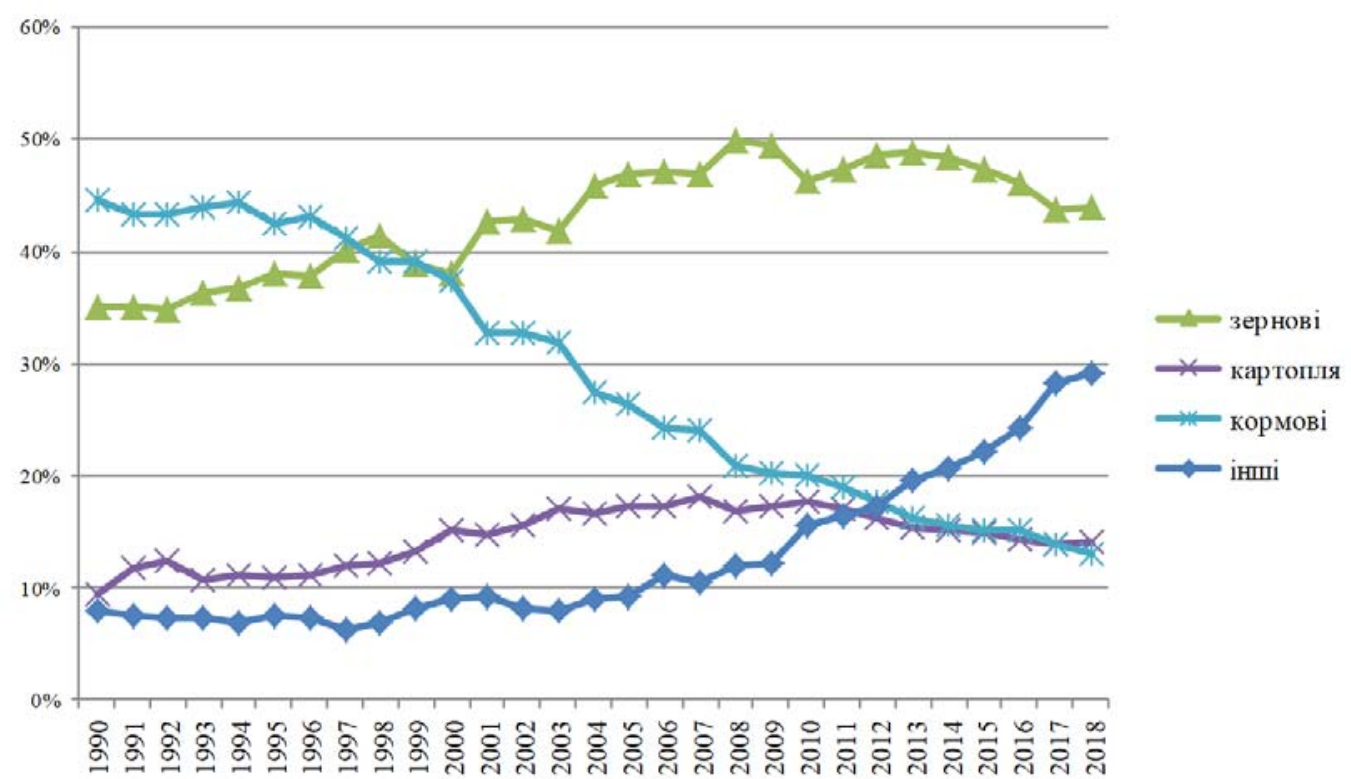

Рис. 2. Динаміка структури посівних площ основних сільськогосподарських культур у Львівській області (побудовано на основі даних (Baza danykh Holovnoho upravlinnia statystyky u Lvivskii oblasti) 
Всього у категорії “інші” об’єднано 5 культур: буряк цукровий, соняшник, соя, ріпак та овочеві культури. Їхню динаміку у вигляді графіка із накопиченням показано на рис. 3.

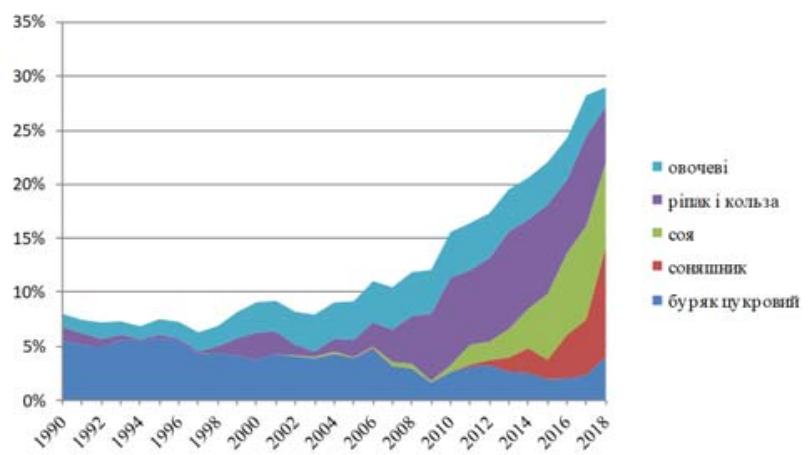

Рис. 3. Динаміка структури посівних площ інших сільськогосподарських культур у Львівській області (побудовано на основі даних (Baza danykh

Holovnoho upravlinnia statystyky u Lvivskii oblasti))

Як бачимо, найбільше зростання останніми роками демонструють соя та соняшник, дещо раніше відбулось зростання частки ріпаку, частка якого за останні 8 років змінюється мало. Зменшуються площі під буряком.

На основі аналізу графіків на рис. 2 і 3 можна стверджувати, що у Львівській області у найближчій перспективі основними культурами залишаються зернові (це на 45\% пшениця озима, 31\% кукурудза на зерно, 7\% ячмінь озимий, по 6\% пшениця та ячмінь ярі і 4\% овес), соя, соняшник та картопля. Розглянемо перспективи залучення ГМ сортів даних культур.

Генетично модифікована пшениця $є$ перспективним напрямом досліджень у біотехнології. Станом на 2015 року жодна ГМ-пшениця ще не вирощувалась на комерційній основі, хоча було проведено уже багато польових випробувань. Пшениця сама по собі є міжвидовим гібридом диких предків (Triticum monococcum, Aegilops speltoides i Aegilops tauschii усі диплоїдні трави). До 2013 р. у Свропі було проведено 34 польових випробування пшениці, а 419 - у США. Бажані модифікації включають ті, які створюють стійкість до гербіцидів, стійкість до комах і до грибкових патогенів (особливо Fusarium) та вірусів, толерантність до посухи та стійкість до солоності грунту й надмірного тепла, намагаються знизити вміст глютеніну, поліпшити харчову цінність (більш високий вміст білка, підвищення термостійкості ферменту фітази, збільшення вмісту водорозчинних харчових волокон, збільшення вмісту лізину), поліпшуються якості для використання як біопаливної сировини, застосування до виробництва лікарських засобів й збільшення врожайності.

Соя - культура, що зазнала чи не найбільше різновидів генних модифікацій із поширенням відповідних сортів у землеробній практиці - у США з 1998 року; станом на 2014 р. в усьому світі офіційно близько $82 \%$ посівів сої належали до ГМО. До найбільш популярних модифікацій сої належать: Roundup ready soybean - стійка до дії гербіцидів (передусім гліфоса- ту) та Vistive Gold або MON 87705 - із поліпшеним синтезом жирних кислот. Загалом ж відомими вважають 13 ліній сої. Варто зазначити, що стійкість до гліфосату (N-(phosphonomethyl)glycine) означає лиш те, що на полі із такою соєю можна більш ефективно позбуватись бур'янів, застосовуючи гербіцид, що $є$ ймовірним канцерогеном для людини (категорія небезпеки “2A").

Всього відомо понад 22 лінії ГМ картоплі, до найвідоміших можна зачислити генетично модифікований сорт картоплі, розроблений BASF Plant Science й відомий як Amflora (також як EH92-527-1). Рослини картоплі цього сорту виробляють чистий амілопектиновий крохмаль. Цей сорт розглядають як технічний і його дозволено вирощувати для технічних потреб у деяких країнах $\mathrm{CC}$, наприклад Німеччині. Також було отримано сорти, стійкі до нематоди, проте лабораторні дослідження показали, що така картопля спричиняє зниження імунітету та численні захворювання внутрішніх органів у піддослідних щурів. Деякі види ГМ картоплі доволі алергенні. Тому в більшості держав ЄС вирощування ГМ-картоплі заборонено.

На ринку України пропонують насіння трансгенного гібриду олійного соняшнику CRESTON FS 799, що заявлений як стійкий до хвороб, шкідливих комах та стресових умов. Його обробляють гербіцидом системної дії імідазолінової групи Свро-Лайтінг, СвроЛенд або Євро-Ланг р.к. для знищення широкого спектру однорічних злакових, багаторічних бур'янів, дводольних бур'янів. Розроблений канадським Холдингом SERTIS і американським хімічним концерном UNION CARBIDE в 2016 р. гібрид є самозапильний, декларується його стійкість до кислотних дощів і короткочасних перепадів температури у межах від -12 до $+60{ }^{\circ} \mathrm{C}$.

У нашій країні також $є$ певний досвід отримання трансгенних організмів. Так, за даними (Levenko, 2011), в Інституті клітинної біології та генетичної інженерії НАН України виведено:

- горох, стійкий до гербіцидів фосфінотрицину, персюїту;

- цукровий буряк 0-типу, стійкий до фосфінотрицину;

- стійкий до фосфінотрицину ріпак;

- салат, тютюн, моркву з людським геном інтерферону альфа-2b;

- салат, цикорій 3 антигеном ESAT6 бактерії Mycobacterium tuberculosis, що викликає туберкульоз (зауважимо, що вакцини і сироватки з рослин - один 3 найперспективніших напрямів біотехнології у світі).

В Інституті фізіології рослин і генетики та Національному ботанічному саду отримано:

- сою, цукровий буряк, картоплю, гречку, стійкі до гербіциду гліфосату;

- виноград, стійкий до фосфінотрицину і бактеріального раку;

- ріпак, олійну редьку 3 геном пірролін-5карбоксилатсинтетази Medicago truncatula, що підвищує вміст проліну, Brassica napus, Raphantus sativus 3 супресором гена проліндегідрогенази 3 підвищеною стійкістю до абіотичних стресів. 
За неофіційними даними, в Україні трансгенні 6070\% сої, 10-20\% кукурудзи, 5\% - ріпаку (Levenko, 2011). Існує декілька робіт, у яких наводять результати досліджень вмісту трансгенних рослин і продуктів в Україні та Львівській області зокрема, наприклад (Kushnir, 2015). Зазвичай інтерес дослідників полягає у виявленні трансгенних продуктів у сировині та продукції рослинництва. Використовують тест-системи переважно іноземного виробництва для виявлення маркерів, присутність яких характерна для ГМ рослин. Дослідження зразків на наявність ГМО проводять зокрема методом полімеразної ланцюгової реакції в режимі реального часу згідно 3 ДСТУ ISO 21569:2008, ДСТУ ISO 21570:2008.

Оскільки на світовому ринку існує попит на генетично модифіковані культури, за оцінками близько $68 \%$ українських агрохолдингів заявляють про бажання та можливості вирощувати ГМ культури за їх легалізації в Україні.

\section{Висновки}

У світі стрімко поширюється використання ГМО у сільському господарстві. Разом із тим ставлення до ГМО у СС та США сильно відрізняється, а тому серед аргументів проти розширення використання цих організмів поряд із екологічними та економічними можуть бути політичні.

У Львівській області основні культури в сільському господарстві становлять зернові (озима пшениця, кукурудза), картопля, стрімко зростає виробництво сої та соняшника. У світовій практиці поширені ГМ сорти сої та кукурудзи. На ринку насіння України пропонують стійкий до погодних умов олійний соняшник, проте погодні умови тут сприятливі й суттєвої переваги він не матиме. 3 ГМ сортів картоплі безпечними вважають сорти технічного призначення (для виробництва крохмалю), ГМ сорти пшениці у світовій практиці наразі не були достатньо апробовані. Таким чином, найбільш перспективними ГМ культурами для сільського господарства Львівщини є соя та кукурудза.

Національний науковий потенціал достатній для проведення досліджень ГМО, проте у законодавстві наразі не вироблено єдиної концепції ставлення до цих організмів та продуктів на їх основі.

\section{References}

Bashuk, V.V. (2017). Formuvannia svitovoho rynku henetychno modyfikovanykh produktiv: dys. na zdobuttia nauk. stupenia kand. ekon. nauk: spets. 08.00.02 "Svitove hospodarstvo i mizhnarodni ekonomichni vidnosyny (in Ukrainian).

Baza danykh Holovnoho upravlinnia statystyky u Lvivskii oblasti [Elektronnyi resurs]. http://database.ukrcensus.gov.ua/MULT/Dialog/statfil e_c.asp.

Davison, J. (2010). GM plants: Science, politics and EC regulations. Plant Science, 178(2), 94-98. doi: 10.1016/j.plantsci.2009.12.005.

Khmara, M.P. (2017). Rol henno-modyfikovanykh produktiv v suchasnomu sviti. Mizhnarodni vidnosyny, Seriia "Ekonomichni nauky", 9. Elektronnyi resurs. http://journals.iir.kiev.ua/index.php/ec_n/article/view/3 121 (in Ukrainian).

Kushnir, H.V. (2015). Doslidzhennia roslynnoi syrovyny na naiavnist henetychno modyfikovanykh dzherel. Naukovo-tekhnichnyi biuleten Instytutu biolohii tvaryn i Derzhavnoho naukovo-doslidnoho kontrolnoho instytutu vetpreparativ ta kormovykh dobavok, 16(1), 100-103 (in Ukrainian).

Levenko, B. (2011). Transhenni kultury u sviti ta Ukraini. Visnyk Natsionalnoi akademii nauk Ukrainy, 9, 3140. http://nbuv.gov.ua/UJRN/vnanu_2011_9_5 (in Ukrainian).

Malus, A.I. (2016). Derzhavne rehuliuvannia obihu HMO v Ukraini, YeS ta SShA. Pravovi zasady funktsionuvannia publichnoi vlady shchodo zabezpechennia intelektualnoho rozvytku ta bezpeky suspilstva: materialy Mizhnarodnoi naukovopraktychnoi konferentsii, Sumy, 19-20 travnia 2016 r. Sumy: SumDU, 86-89 (in Ukrainian).

Oblat, R.V. (2014). Monitorynh produktiv kharchuvannia ta silskohospodarskoi syrovyny $\mathrm{v}$ Ukraini na vmist henetychno modyfikovanykh inhrediientiv. Visnyk ahrarnoi nauky, 1, 59-63. http://nbuv.gov.ua/UJRN/ vaan_2014_1_16 (in Ukrainian).

Rudyshyn, S.D. (2011). Henetychno modyfikovani roslyny: problemy i perspektyvy vykorystannia. Nauka ta innovatsii, 7(6), 5-13. http://dspace.nbuv.gov.ua/handle/123456789/115878 (in Ukrainian).

Zakon Ukrainy "Pro derzhavnu systemu biobezpeky pry stvorenni, vyprobuvanni, transportuvanni ta vykorystanni henetychno modyfikovanykh orhanizmiv" vid 31.05.2007 1103-V. Rezhym dostupu: http://zakon5.rada.gov.ua/laws/show/110316 (in Ukrainian). 